\section{Influence of the age of Ctenocephalides felis felis (Siphonaptera, Pulicidae) adults on the response to fipronil in in vitro testing}

\author{
Influência da idade de Ctenocephalides felis felis (Siphonaptera, \\ Pulicidae) adultos na resposta ao fipronil em teste in vitro
}

\author{
Renan Bernardes Tavares ${ }^{1}$ (D), Gabriela Pereira Salça de Almeida² (1), Jessica Karoline Oliveira Chaves² (D), \\ Diefrey Ribeiro Campos ${ }^{3}$ (D) , Thaís Ribeiro Correia ${ }^{4}$ (D) \\ VVeterinarian Student, PIBIC/CNPq scientific initiation scholarship, Universidade Federal Rural do Rio de Janeiro - UFRRJ, \\ Seropédica-RJ, Brazil \\ ² Veterinarian, Msc. Departamento de Parasitologia Animal, Universidade Federal Rural do Rio de Janeiro - UFRRJ, Seropédica, \\ RJ, Brasil \\ ${ }^{3}$ Veterinarian, Dr. Departamento de Parasitologia Animal, Universidade Federal Rural do Rio de Janeiro - UFRRJ. Seropédica, RJ, Brasil \\ ${ }^{4}$ Veterinarian, Dr. Programa de Pós-graduação em Ciências Veterinárias - PPGCV, Universidade Federal Rural do Rio de Janeiro \\ - UFRRJ, Seropédica, RJ, Brasil
}

\begin{abstract}
Ctenocephalides felis felis is an ectoparasite of the Siphonaptera order with great importance in veterinary medicine and public health. The objective of this work was to evaluate the influence of different ages of unfed adults of the $C$. felis felis subspecies on the susceptibility to fipronil when submitted to in vitro testing. The adult fleas used were obtained from a laboratory colony and the method used was impregnation of filter paper sheets with fipronil at concentration of $0.008 \mathrm{mg} . \mathrm{cm}^{-2}$. Eight experimental groups were formed (four control and four treated), according to the age of the fleas ( $0,7,14$ and 21 days). The mortality evaluation criterion used was motility, assessed 24 and 48 hours after exposure to the drug. After 24 hours, the fleas with age of 21 days suffered 100\% mortality, a figure that declined among as the age became younger. The mortality was $98.3 \%$ among the fleas with age of 14 days, 93.1\% among those with 7 days of age, and 86.7\% among those just hatched (0 days). Exposure to fipronil after 48 hours caused 100\% mortality among all age groups. Based on the results, it can be concluded that the fleas' age did not influence the response to the in vitro tests of susceptibility to fipronil after 24 and 48 hours.
\end{abstract}

Keywords: flea, phenylpyrazoles, efficacy.

\section{Resumo}

Ctenocephalides felis felis é um ectoparasito da ordem siphonaptera de grande importância na medicina veterinária e na saúde pública. Este trabalho teve como objetivo avaliar a influência de diferentes idades de pulgas adultas da espécie $C$. felis felis na suscetibilidade ao fipronil quando submetidas à teste in vitro. Foram utilizadas pulgas adultas oriundas de colônia laboratorial de C. felis felis. A metodologia utilizada foi de impregnação de papel filtro com fipronil na concentração de $0,008 \mathrm{mg} \cdot \mathrm{cm}^{-2}$. Foram formados oito grupos experimentais, de acordo com a idade das pulgas (Grupos de 0, 7,14 e21 dias). O critério de avaliação utilizado foi a motilidade, avaliada nos períodos de 24 e 48 horas após o desafio. Após 24 horas as pulgas com 21 dias de eclodidas obtiveram índice de $100 \%$ de mortalidade, que diminuiu de acordo com a idade. As pulgas com 14 dias obtiveram 98,3\% de mortalidade, 7 dias 93,1\% e com 0 dias 86,7\%. No período de 48 horas, o fipronil apresentou 100\% de eficácia em todos as idades. Com base nos resultados pode-se concluir que a idade da pulga não influenciou na resposta do teste in vitro quanto a suscetibilidade ao fipronil, em 24 e 48 horas.

Palavras-chave: pulga, fenilpirazole, eficácia.

\section{Introduction}

Fleas are ectoparasites with great importance in veterinary medicine, associated with their ability to transmit various infectious and parasitic diseases that afflict animals and humans (Soulsby, 1968; Booth \& Mcdonald, 1982; Oliveira et al., 2002; Márquez et al., 2002). In Brazil, the main species are those of the Pulicidae family, especially Xenopsylla cheopis Rothschild, 1903, Pulex irritans Linnaeus, 1758, Ctenocephalides canis Curtis, 1826 and Ctenocephalides felis felis
How to cite: Tavares, R. B., Almeida, G. P. S., Chaves, J. K. O., Campos, D. R., \& Correia, T. R. (2020). Influence of the age of Ctenocephalides felis felis (Siphonaptera, Pulicidae) adults on the response to fipronil in in vitro testing. Brazilian Journal of Veterinary Medicine, 42, e107920. http://doi.org/10.29374/2527-2179.bjvm107920

Financial support: Fundação de Apoio à Pesquisa Científica e Tecnológica da UFRRJ - FAPUR

Conflict of interests: No conflict of interests declared concerning the publication of this article.

Received: September 28, 2019

Accepted: March 07, 2020

The study was carried out at Departamento de Parasitologia Animal, Laboratório de Quimioterapia Experiemntal em Parasitologia Animal, Instituto de Veterinária, Universidade Federal Rural do Rio de Janeiro, Rio de Janeiro, RJ, Brasil.

\section{*Correspondence}

Thais Ribeiro Correia Azevedo

Departamento de Parasitologia Animal, Universidade Federal Rural do Rio de Janeiro UFRRJ, Campus Seropédica

Rodovia BR 465, Km 07, s/n Zona Rural CEP 23890-000 - Seropédica (RJ), Brasil E-mail: Thaisrca@gmail.com
Copyright Tavares et al. This is an Open Access article distributed under the terms of the Creative Commons Attribution Non-Commercial License which permits unrestricted non-commercial use, distribution, and reproduction in any medium provided the original work is properly cited. 
Bouché, 1835. Among these, the principal subspecies of flea found on pets is C. felis felis, due to its wide distribution and ability to parasitize various categories of hosts (Linardi \& Santos, 2012).

Fleas complete their metamorphosis in four stages: egg, three larval phases, pupa and adult, with an average biological cycle ranging from 25 to 30 days, although this can vary according to the temperature, humidity and food availability in the larval phases (Linardi \& Nagem 1972). Only $5 \%$ of fleas are found on hosts, with the other 95\% being present in the environment in different stages, hampering their control (Dryden et al., 2013). Therefore, mechanical, biological and chemical control measures need to be applied in association to prevent or ameliorate infestations and the diseases spread by these ectoparasites.

Besides just preventing diseases, control of fleas aims to preserve the comfort and overall welfare of the host because of the severe stress caused by their bites. Therefore, infested animals should whenever possible be treated before the fleas start reproduction (Byron, 1987; Dryden \& Prestwood, 1993; Rust, 1994).

Fipronil is an insecticide belonging to the pyrazole class. Its main chemical component is phenylpyrazole, which besides having good selectivity for insects (Hainzl \& Casida 1996, Narahashi et al., 2010), also has herbicidal activity (Cole et al., 1993). It is an ectoparasiticide used globally to control flea and tick infestations on dogs and cats (Taylor, 2001). It works by blocking the passage of chlorine ions regulated by gamma aminobutyric acid (GABA), thus interfering in the parasite's neuromodulation mechanism, leading to hyperexcitation of nerve cells and causing death (Blagburn \& Dryden, 2009). Fipronil exerts its effect on adult fleas by contact, enabling killing them before their first blood meal (Tanner et al., 1997), which is very important to prevent diseases and allergic reactions of animals. Its efficacy can thus be tested in vitro through exposure of fleas to the drug, a method that is easy to perform, inexpensive and does not require sophisticated equipment, besides minimizing the use of laboratory animals as hosts of adult fleas.

The objective of this study was to evaluate the influence of age of unfed adult fleas of the subspecies $C$. felis felis in response to exposure to fipronil via the in vitro filter paper impregnation test.

\section{Material and methods}

The fleas used in this study were obtained from eggs collected from a colony of $C$. felis felis maintained on cats in the Laboratory of Experimental Chemotherapy in Animal Parasitology of the Veterinary Institute of Federal Rural University of Rio de Janeiro. The study was approved by the university's committee on ethical use of animals (protocol number 091/2014).

The eggs collected were examined for defects, identified and then incubated in containers for hatching. In the containers, the eggs were placed on a substrate of dehydrated bovine blood, wheat bran and sand, in proportion of 1:1:5, to enrich the environment. The containers containing the eggs were incubated in biochemical oxygen demand (BOD) chambers at a temperature of $27 \pm 1^{\circ} \mathrm{C}$ and relative humidity of $75 \pm 5 \%$ for hatching and development of the fleas, which were monitored daily until they reached the adults stage.

A total of 480 unfed adult fleas with ages of 0, 7,14 and 21 days were used in the experiment. Each age group was subdivided into a control (untreated) and treated group. There were six repetitions per group, each formed of 10 fleas ( 5 males and 5 females), kept in test tubes (18 x $150 \mathrm{~mm}$ ) sealed with non-woven tissue and elastic bands, which were incubated in vertical position in BOD chambers at temperature of $27 \pm 1^{\circ}$ and relative humidity of $75 \pm 10 \%$.

The fipronil concentration used was based on the recommendation of Batista et al. (2016) of $400 \mathrm{ppm}$, adjusted to $462 \mathrm{ppm}$, corresponding to $0.008 \mathrm{mg} \mathrm{cm}^{-2}$, for adequacy of the impregnation volume. According to the method described by Burden \& Smittle (1968), the insecticide was impregnated on filter paper strips with area of $7.5 \mathrm{~cm}^{2}$. Each strip was impregnated with 130 $\mu \mathrm{L}$ of fipronil at concentration of $0.008 \mathrm{mg} . \mathrm{cm}^{-2}$. For comparison, the filter paper strips for the control groups were impregnated with the same volume of acetone. Each tube was identified as to group and incubated in a climate-controlled chamber [BOD chamber] for 24 or 48 hours.

The criterion for evaluation of mortality was motility, i.e., when any movement was detected, even slight, the specimen was considered to be alive. 
The efficacy of each age group was represented by the formula: Efficacy (\%) = [(average number of live fleas of the control group - average number of live fleas of the treated group) / average number of live fleas of the control group] x 100 (Abbott, 1925).

The data were tested for normal distribution by the Shapiro-Wilk test, and the averages of the the control and treated groups after each age were compared by the Mann-Whitney test. The ages were compared between each other within each group by analysis of variance by the KruskalWallis test. The level of significance was 95\% in all the tests, and computations were carried out with the free software BioEstat 5.3 (Ayres et al., 2007).

\section{Results}

The results are reported in Table 1 . The average numbers of living fleas in the control groups for ages of 0, 7, 14 and 21 days were 10, 9.7, 9.8 and 10, respectively for 24 hours, and 10, 9.7, 8.8 and 10, respectively, for 48 hours after exposure.

Table 1. Evaluation of the influence of age of unfed Ctenocephalides felis felis fleas in response to in vitro testing of the insecticide fipronil by the impregnated filter paper method.

\begin{tabular}{|c|c|c|c|c|c|c|c|c|}
\hline \multirow{3}{*}{$\begin{array}{l}\text { Groups/ } \\
\text { Repetition }\end{array}$} & \multicolumn{8}{|c|}{ Number of living fleas/Evaluation period/Age (in days) } \\
\hline & \multicolumn{4}{|c|}{24 hours } & \multicolumn{4}{|c|}{48 hours } \\
\hline & 0 days & 7 days & $\begin{array}{c}14 \\
\text { days }\end{array}$ & $\begin{array}{c}21 \\
\text { days }\end{array}$ & 0 days & 7 days & $\begin{array}{c}14 \\
\text { days }\end{array}$ & $\begin{array}{c}21 \\
\text { days }\end{array}$ \\
\hline \multicolumn{9}{|l|}{ Control } \\
\hline 1 & 10 & 10 & 10 & 10 & 10 & 10 & 9 & 10 \\
\hline 2 & 10 & 9 & 10 & 10 & 10 & 9 & 10 & 10 \\
\hline 3 & 10 & 9 & 9 & 10 & 10 & 9 & 7 & 10 \\
\hline 4 & 10 & 10 & 10 & 10 & 10 & 10 & 8 & 10 \\
\hline 5 & 10 & 10 & 10 & 10 & 10 & 10 & 10 & 10 \\
\hline 6 & 10 & 10 & 10 & 10 & 10 & 10 & 9 & 10 \\
\hline Arithmetic mean & 10.0 & 9.7 & 9.8 & 10.0 & 10.0 & 9.7 & 8.8 & 10.0 \\
\hline Standard deviation & 0.0 & 0.5 & 0.4 & 0.0 & 0.0 & 0.5 & 1.2 & 0.0 \\
\hline \multicolumn{9}{|l|}{ Treated (Fipronil) } \\
\hline 1 & 3 & 2 & 0 & 0 & 0 & 0 & 0 & 0 \\
\hline 2 & 0 & 0 & 0 & 0 & 0 & 0 & 0 & 0 \\
\hline 3 & 1 & 0 & 0 & 0 & 0 & 0 & 0 & 0 \\
\hline 4 & 0 & 0 & 1 & 0 & 0 & 0 & 0 & 0 \\
\hline 5 & 1 & 1 & 0 & 0 & 0 & 0 & 0 & 0 \\
\hline 6 & 3 & 1 & 0 & 0 & 0 & 0 & 0 & 0 \\
\hline Arithmetic mean & 1.3 & 0.7 & 0.2 & 0.0 & 0.0 & 0.0 & 0.0 & 0.0 \\
\hline Standard deviation & 1.4 & 0.8 & 0.4 & 0.0 & 0.0 & 0.0 & 0.0 & 0.0 \\
\hline P-value* & 0.0039 & 0.0039 & 0.0039 & 0.0039 & 0.0039 & 0.0039 & 0.0039 & 0.0039 \\
\hline Efficacy (\%) & 86.7 & 93.1 & 98.3 & 100.0 & 100.0 & 100.0 & 100.0 & 100.0 \\
\hline
\end{tabular}

*The $p$-value indicates that the means within the same column differ significantly $(p \leq 0.05)$

In the treated groups with different ages, the average numbers of living fleas after 24 hours were $1.3,0.7,0.2$ and 0 , respectively for 0, 7,14 and 21 days of age. After 48 hours, no fleas remained alive in any of the age groups.

The average mortality rates between the control and treated groups for all the ages in the periods of 24 and 48 hours differed significantly ( $\leq \leq 0.05$ ). In turn, the average numbers of living fleas of different ages within the control group and within the treated group after 24 hours were 
not statistically different. In the control groups, there were significant differences between ages of 0 and 14 days ( $\mathrm{p}=0.0412$ ) and between 14 and 21 days ( $\mathrm{p}=0.0412$ ). In the period of 48 hours, it was not possible to analyze the averages since no fleas in the treated groups at any age survived

With respect to the efficacy of fipronil, the averages were 86.7, 93.1, 98.3 and 100\%, respectively, for fleas with ages of 0, 7, 14 and 21 days after 24 hours of exposure, while after 48 hours it was $100 \%$ for all ages.

\section{Discussion}

The evaluation of the efficacy of insecticides by the filter paper impregnation method is a standard laboratory method recommended by the World Health Organization (WHO). Researchers can use fleas from their own colonies or acquire them commercially (El-Gazzar et al., 1986). Therefore, all manipulation history should be considered when defining an in vitro test. Besides this, few researchers have reported the age of the ticks used in evaluating insecticides.

Our results demonstrate that the age of unfed adult ticks did not influence the efficacy of fipronil in the in vitro test. Despite the numerical differences in the efficacy percentages, these were not statistically significant. The fleas with age of 21 days were more susceptible than those with 0 days of age, although the average value was low. Similar results were reported by El Gazzar et al. (1988), who found that the mortality rates of fleas increased significantly after 3 days of age.

In the control group, the mortality rate was highest among the fleas with 7 and 14 days of age, and this percentage was higher for the 14-day-old fleas in the period of 48 hours, although the difference was not significant. Due to the scarcity of studies evaluating the influence of the age of fleas used in in vitro tests, it is only possible through extrapolation to assume that younger fleas are more resistant to insecticides and take longer to die than the older fleas because of the greater energy reserves in younger fleas and the lesser manipulation given to them.

\section{Conclusion}

The results showed that the flea age did not significantly influence the response to the in vitro test of susceptibility to fipronil, despite the numerical variation observed in the exposure period of 24 hours.

\section{References}

Abbott, W. S. (1925). A method of computing the effectiveness of an insecticide. Journal of Economic Entomology, 18(2), 265-267. http://dx.doi.org/10.1093/jee/18.2.265a.

Ayres, M., Ayres, J. R. M., Ayres, D. L., \& Santos, A. S. (2007). BioEstat 5.O: aplicações estatísticas nas áreas das ciências biológicas e médicas (290p.). Belém: Sociedade Civil Mamirauá. Brasília: CNPq.

Batista, L. C., Cid, Y. P., De Almeida, A. P., Prudêncio, E. R., Riger, C. J., De Souza, M. A., Coumendouros, K., \& Chaves, D. S. (2016). Eficácia in vitro de óleos essenciais e extratos de Schinus molle L. contra Ctenocephalides felis felis. Parasitology, 143(5), 627-638. http://dx.doi.org/10.1017/S0031182016000081. PMid:26887529.

Blagburn, B. L., \& Dryden, M. W. (2009). Biology, treatment, and control of flea and tick infestations. The Veterinary Clinics of North America. Small Animal Practice, 39(6), 1173-1200, viii. http://dx.doi.org/10.1016/j. cvsm.2009.07.001. PMid:19932369.

Booth, N., \& McDonald, L. (1982). External parasite control. Veterinary Pharmacology and Therapeutics (5. ed., pp. 892-925) Ames, IA: Iowa State University Press.

Burden, G. S., \& Smittle, B. J. (1968). Laboratory methods for evaluation of toxicants for the bed bug and oriental rat flea. Journal of Economic Entomology, 61(6), 1565-1567. http://dx.doi.org/10.1093/jee/61.6.1565. PMid:5723756.

Byron, D. W. (1987). Aspects of the biology, behavior, bionomics, and control of immature stages of the cat flea, Ctenocephalides felisfelis (Bouche) (Siphonaptera: Pulicidae), in the domiciliar environment (Doctoral dissertation). Virginia Polytechnic Institute and State University, Blacksburg.

Cole, L. M., Nicholson, R. A., \& Casida, J. E. (1993). Action of phenylpyrazole insecticides at the GABA-gated chloridchannel. Pesticide Biochemistry and Physiology, 46(1), 47-54. http://dx.doi.org/10.1006/pest.1993.1035.

Dryden, M. W., \& Prestwood, A. K. (1993). Successful flea control. The Compendium on Continuing Education for the Practicing Veterinarian, 15(6), 821-831.

Dryden, M. W., Payne, P. A., Smith, V., Berg, T. C., \& Lane, M. (2013). Efficacy of selamectin, spinosad, and spinosad/ milbemycin oxime against the KS1 Ctenocephalides felis flea strain infesting dogs. Parasites \& Vectors, 6(1), 80. http://dx.doi.org/10.1186/1756-3305-6-80. PMid:23531322. 
El-Gazzar, L. M., Milio, J., Koehler, P. G., \& Patterson, R. S. (1986). Insecticide resistance in the cat flea (Siphonaptera: Pulicidae). Journal of Economic Entomology, 79(1), 132-134. http://dx.doi.org/10.1093/jee/79.1.132. PMid:3950184.

El-Gazzar, L. M., Koehler, P. G., \& Patterson, R. S. (1988). Factors affecting the susceptibility of the cat flea, Ctenocephalides felis Bouché, to chlorpyrifos. Journal of Agricultural Entomology, 5(2), 127-130.

Hainzl, D., \& Casida, J. E. (1996). Fipronil insecticide: novel photochemical desulfinylation with retention of neurotoxicity. Proceedings of the National Academy of Sciences of the United States of America, 93(23), 1276412767. http://dx.doi.org/10.1073/pnas.93.23.12764. PMid:8917493.

Linardi, P. M., \& Nagem, R. L. (1972). Observações sobre o ciclo evolutivo de Ctenocephalides felis (Bouché, 1835) (Siphonaptera, Pulicidae) e sua sobrevida fora do hospedeiro. Boletim do Museu de História Natural UFMG Zoologia, 13, 1-22.

Linardi, P. M., \& Santos, J. L. C. (2012). Ctenocephalides felis felis vs. Ctenocephalides canis (Siphonaptera: Pulicidae): some issues in correctly identify these species. Revista Brasileira de Parasitologia Veterinária, 21(4), 345-354. http://dx.doi.org/10.1590/S1984-29612012000400002. PMid:23295817.

Márquez, F. J., Muniain, M. A. A., Pérez, J. M., \& Pachón, J. (2002). Presence of Rickettsia felis in the cat flea from southwestern Europe. Emerging Infectious Diseases, 8(1), 89-91. http://dx.doi.org/10.3201/eid0801.010193. PMid:11749758.

Narahashi, T., Zhao, X., Ikeda, T., Salgado, V. L., \& Yeh, J.Z. (2010). Glutamate-activated chloride channels: unique fipronil targets present in insects but not in mammals. Pesticide Biochemistry and Physiology, 97(2), 149-152. http://dx.doi.org/10.1016/j.pestbp.2009.07.008. PMid:20563240.

Oliveira, R. P., Galvão, M. A., Mafra, C. L., Chamone, C. B., Calic, S. B., Silva, S. U., \& Walker, D. H. (2002). Rickettsia felis in Ctenocephalides spp. fleas, Brazil. Emerging Infectious Diseases, 8(3), 317-319. http://dx.doi.org/10.3201/ eid0803.010301. PMid:11927031.

Rust, M. K. (1994). Interhost movement of adult cat fleas (Siphonaptera: Pulicidae). Journal of Medical Entomology, 31(3), 486-489. http://dx.doi.org/10.1093/jmedent/31.3.486. PMid:8057325.

Soulsby, E. J. L. (1968). Fleas. In E. J. L. Soulsby. Helminths, arthropods and protozoa of domestic animals (6th ed., pp. 383-389). Baltimore: The Williams \& Wikins, CO.

Tanner, P. A., Meo, N. J., Sparer, D., Butler, S. J., \& Keister, D. M. (1997). Advances in the treatment of heartworm, fleas and ticks. Canine Practice, 22, 40-47.

Taylor, M. A. (2001). Recent developments in ectoparasiticides. Veterinary Journal (London, England : 1997), 161(3), 253-268. http://dx.doi.org/10.1053/tvjl.2000.0549. PMid:11352483.

WHO Expert Committee on Insecticides, \& World Health Organization - WHO. (1963). Insecticide resistance and vector control: thirteenth report of the WHO Expert Committee on Insecticides [meeting held in Geneva from 20 to 26 November 1962] (World Health Organization technical report series, No. 265). Geneva: WHO. 